\title{
Wealth Effects out of Financial and Housing Wealth: Cross Country and Age Group Comparisons
}

\author{
Eva Sierminska \\ Luxembourg Income Study and DIW Berlin \\ Yelena Takhtamanova \\ Federal Reserve Bank of San Francisco
}

January 2007

Working Paper 2007-01

http://www.frbsf.org/publications/economics/papers/2007/wp07-01bk.pdf

The views in this paper are solely the responsibility of the authors and should not be interpreted as reflecting the views of the Federal Reserve Bank of San Francisco or the Board of Governors of the Federal Reserve System. 


\title{
WEALTH EFFECTS OUT OF FINANCIAL AND HOUSING WEALTH: CROSS COUNTRY AND AGE GROUP COMPARISONS ${ }^{+}$
}

\author{
Eva Sierminska*
}

\author{
Yelena Takhtamanova**
}

\section{December 2006}

\begin{abstract}
To explore the link between household consumption and wealth, we use a new source of harmonized microdata (Luxembourg Wealth Study). We investigate whether there are differences in wealth effects from different types of wealth and across age groups. We consider three countries: Canada, Italy and Finland. We find that the overall wealth effect from housing is stronger than the effect from financial wealth for the three countries in the sample. Additionally, in accordance with the life-cycle theory of consumption, we find the housing wealth effect to be significantly lower for younger households. We also find between-country differences in the wealth effect.
\end{abstract}

JEL classification: D1, J1

\section{Keywords: Household Behavior, Wealth Effect, Consumption}

\footnotetext{
${ }^{+}$The authors would like to thank Andrea Brandolini, Sean Corcoran, Renee Courtois, Mary Daly, Karen Dynan, Frederick Furlong, Jessica Howell, Nancy Jianakopolis, Arthur Kennickell, Kevin Moore, Jiri Slacalek, Daniel Wilson, Gary Zimmerman, and the participants of the Federal Reserve Bank of San Francisco Brownbag Seminar Series, IARIW 2006 general conference, and WEA 2005 annual meetings for helpful suggestions and comments.

* Luxembourg Income Study and DIW Berlin, 17 rue des Pommiers, L-2343 Luxembourg, email: sierminska@lisproject.org.

** Federal Reserve Bank of San Francisco, 101 Market Street, MS 1130, San Francisco, CA 94105, USA, email: yelena.takhtamanova@sf.frb.org
} 


\section{$1 \quad$ Introduction}

The link between wealth and consumption, known as the wealth effect, has been of interest to economists for decades, but the late 1990s mark the beginning of renewed interest in the literature (Dynan and Maki 2001). This renewal of interest was sparked by the dramatic increases in stock values during the economic expansion of the late 1990s. It was later fueled by the rapid appreciation and recent softening in house prices in the U.S. and many other industrialized countries. These recent developments in the housing market raise the question of how households view their housing wealth and how that might affect consumption.

While at its early stages the literature did not address differences in consumption responses to shocks to different types of wealth, many authors recognized that overall wealth may not contain all the information useful for understanding the link between wealth and consumption spending. In particular, arguments have been made to separate wealth into financial and housing components (see, for example, Boone and Girouard 2002, Bostic et al. 2005, Carroll 2004, Case et al. 2001, Pichette and Tremblay 2003, and Poterba and Samwick 1995). This is because financial and housing assets likely have different features that might affect the propensity to consume out of wealth,.such as liquidity, trackability, permanence of shocks, and perceived appropriateness for financing consumption.

Considering the impact of the consumer's age on the strength of the wealth effect also proves appropriate. Standard economic theories (Gourinchas and Parker 2002) and empirical evidence (Hurd and Rohwedder 2005, Lehnert 2004, Hoynes and McFadden 1994, Venti and Wise 2001) give us reasons to expect consumption of older households to be more sensitive to wealth shocks than that of young households. This is a potentially important insight in light of the population aging that is taking place around the globe as a result of decreasing fertility and 
increasing life expectancy. If the wealth effect truly does vary by age groups, then the strength of the aggregate wealth effect might change as a result of the aforementioned demographic changes.

Our paper contributes to the literature in two important ways. First, we analyze age differences in the wealth effect out of financial and housing wealth in a cross-national context. Previous literature has looked at the heterogeneity of the wealth effect by age to a small extent in single-country studies. Second, our analysis is among the first to be based on cross-country comparable microdata. We use harmonized data for three countries (Canada, Finland, and Italy) from a new data source, the Luxembourg Wealth Study (LWS).

The paper begins with an overview of the existing empirical evidence and the theoretical background for our work. The next two sections outline the methodology and data. Section 5 shows the results of our empirical investigation. Section 6 concludes.

\section{Previous Research and Background}

We base our work on the basic life-cycle model. In this framework, a typical consumer will spread out the benefit or deficit from an unexpected gain or loss in wealth by boosting or cutting current spending by a fraction of the value of the change in wealth and maintain that new level of spending over time. Not all wealth is the same, however, and researchers have argued that it makes sense to distinguish between financial asset wealth and housing wealth, because the characteristics of each may have different effects on people's propensity to consume. Thus, our empirical model allows for different consumption response to different types of wealth. 


\subsection{Wealth Effects and Asset Types}

The solution to a life-cycle model (see, for instance, Modigliani Brumberg 1954) shows that current consumption depends linearly on current (labor) income, average income expected over the earning span, and current asset holding. One important feature of the model is that it suggests that the marginal propensity to consume (MPC) out of wealth increases with the age of the consumer.

This basic life-cycle model does not allow for different MPCs out of different types of wealth. Additionally, it does not allow for capital market imperfections or for information asymmetry. Thus, it cannot be used to answer questions about the influence of liquidity constraints, imperfect information, and transaction costs on the timing and magnitude of the MPC out of wealth (Belsky and Prakken 2004).

\subsection{Possible Reasons for Differences in Financial and Housing Wealth Effects}

Although standard theories used to analyze the link between consumption and wealth (the permanent income hypothesis of Friedman (1957), and the Ando and Modigliani (1963) lifecycle model) do not distinguish between different types of wealth, there are several reasons for expecting a difference in the effects of changes in housing wealth and financial wealth on consumption. To begin with, housing is both an asset and a consumption item. Increases in house prices may indeed lead to an increase in one's wealth, but they also lead to a higher cost of housing services. Thus, an increase in relative house price does not necessarily lead to an increase in a household's overall ability to consume more of other goods and services. This argument would lead a researcher to expect a lower MPC from housing wealth than from 
financial wealth. On the other hand, households can access some of the equity to support consumption by assuming greater debt backed by the wealth of their house.

The literature suggests that agents' awareness of changes in these two types of wealth may differ (Dvornak and Kohler 2003, Case et al. 2005). There is no consensus among authors about which type of wealth is more "trackable" (that is, easier to measure accurately). Some argue that it may be easier to find information on current financial wealth than on current real estate wealth, as houses are less homogenous and are less frequently traded than shares (Dvornak and Kohler, 2003). Thus, an increase in financial wealth may lead to a larger increase in consumption than an equivalent increase in housing wealth. In contrast, it has been suggested that from 1989 to 1995 in the U.S. there seemed to be a trend away from direct ownership of corporate stock and toward ownership through financial intermediaries (Poterba and Samwick 1995). Those who own stock indirectly might be less aware of the current value of their portfolio than direct stock owners. Additionally, an estimate of the value of one's current housing wealth could be derived by using information on sale prices of comparable houses in one's neighborhood.

Housing wealth and financial wealth also differ in terms of liquidity. Housing wealth tends to be viewed as less liquid than financial wealth (Dvornak and Kohler 2003). It may be difficult to liquidate just a part of one's house (which is why housing is often referred to as a "lumpy" asset), whereas liquidating a small portion of one's financial wealth has relatively low costs. ${ }^{1}$ From this standpoint, we would expect to see a higher marginal propensity to consume out of financial wealth than out of housing wealth. This being said, it is reasonable to hypothesize that the relative degree of liquidity of housing wealth and financial wealth differs across countries according to the differences in financial market developments.

\footnotetext{
${ }^{1}$ The decline in costs of home equity loans and mortgage refinancing have reduced the lumpiness of housing assets.
} 
Households may view changes in housing wealth as more permanent than changes in financial wealth (Pichette and Tremblay 2003). In that case, one would expect households to be more willing to increase their consumption following an increase in housing wealth than an increase in financial wealth.

Finally, households may put different types of wealth into different "mental accounts" and, therefore, view changes in the value of some assets as more appropriate to use for current consumption than others (Shefrin and Thaler 1988). We would expect to see a higher MPC out of financial wealth if households perceive changes in housing wealth to be more appropriate for long-term savings.

\subsection{Macroeconomic Evidence}

In the past decade, several studies used macroeconomic data to assess the effect of housing and financial wealth on consumption. Some of those studies do suggest that consumption reacts differently to changes in the two types of wealth. A summary of selected empirical results reviewed by the authors can be found in Appendix Table A.1.

The results on relative sizes of the wealth effects are mixed. In the U.S. and Canada, the estimated wealth effect out of housing wealth exceeds that out of financial wealth (Davis and Palumbo 2001, Carroll 2004, Pichette and Tremblay 2003). However, there is no consensus on the statistical significance of these differences. In the Davis and Palumbo (2001) study, the difference between the wealth effects is marginally significant. Yet, Carroll (2004) pointed out that their results may be biased due to the implicit assumption of a constant saving rate and real interest rate over time. Using an alternative technique for estimating the wealth effect, Carroll 
also found a higher wealth effect out of housing wealth, although the difference between MPCs out of the two types of wealth was not statistically significant.

The lack of variation in aggregate house prices makes it difficult to estimate the wealth effect from housing wealth precisely. Some empirical investigations address this issue by using international or regional data. For example, Case et al. (2005), use U.S. state-level data and find results qualitatively similar to Davis and Palumbo (2001). They also find a significantly higher housing wealth effect for a panel of 16 OECD countries. On the other hand, Ludwig and Slok (2004) use a panel of 14 OECD countries and find a larger financial wealth effect. In Australia, Dvornak and Kohler (2003) use state-level data and also find the financial wealth effect to be stronger than the housing wealth effect.

Using aggregate data or even regional data for studying the wealth effect can also be problematic, because movements in aggregate wealth are likely to be endogenous (Carroll 2004, Dolmas 2003) since movements in asset prices can be affected by many factors that also affect consumption decisions ("most notably, overall macroeconomic prospects," states Carroll 2004).

\subsection{Microeconomic Evidence}

There have been few studies using microdata to address the link between housing wealth and savings. Most of them do not distinguish between different types of wealth (see Table A.1), are single-country studies, and use different methodologies.

In terms of the relative size of financial and housing wealth effects, Bostic et al. (2005) find that, for a sample of U.S. homeowners, sensitivity of consumption spending with respect to financial wealth is smaller than with respect to to housing wealth. Grant and Peltonen (2005) use Italian household data and find that, for all households in the sample, consumption elasticity 
with respect to housing wealth is 0.8 percent but statistically insignificant, and consumption elasticity with respect to equity wealth is around 0.5 percent and significant. Disney et al. (2003) estimate the effect of unanticipated housing gains on active saving for the U.K. and find average MPCs from real housing gains to be between .09 and .14 over the period 1993 to 2001, but they do not look at financial assets.

Some micro studies also focus on age differences in wealth effects. For example, Hoynes and McFadden (1994) examine housing and nonhousing saving rates and find no evidence that households in the U.S. adjust their nonhousing saving in response to expectations about capital gains in housing. Campbell and Cocco (2005) also use microdata for the U.K., and examine the effect of house prices on consumption. They find the largest effect for older homeowners. Bover (2005) examines the patterns of wealth effects on consumption in Spain and finds a stronger effect of housing for prime-age adults and an insignificant financial effect.

The microdata from the Luxembourg Wealth Study provide us with cross-country comparable data. Hence we are able to estimate and compare financial and housing wealth effects in a cross-national context, which was not possible for previous authors.

\section{$3 \quad$ Empirical Specification and Methods}

The model specification standard in the literature is a reduced-form model that relates consumption to wealth, controlling for income and sociodemographic characteristics of the household:

$$
\log (C)=\alpha \log (F W)+\beta \log (H W)+\delta \log (Y)+\sum_{j=0}^{J} \gamma_{j} O_{j}
$$

where $C$ stands for consumption, $H W$ stands for housing wealth, $F W$ stands for financial wealth, $Y$ stands for current income, and $O$ stands for sociodemographic characteristics of the household. 
Using logs of monetary variables (expenditures, wealth, and income) is the preferred specification in the wealth effect literature (see, for instance, Bostic et al. 2005, Dynan and Maki 2001, and Lehnert 2004). The household characteristics included are standard to the literature (see Appendix B for a complete list of household characteristics used). These variables are included to control for preference heterogeneity across households that may be correlated with demographic characteristics of the households, as well as life-cycle effects on the propensity to consume. Additionally, sociodemographic characteristics control for permanent income (Goodman and Kawai 1982).

We are most interested in comparing $\alpha$ and $\beta$. First, we determine the difference between the two and compare the differences across countries. To examine the robustness of our results, equation (1) is estimated for total household expenditures and nondurable expenditures. ${ }^{2}$

In the first specification, sociodemographic variables affect only the intercept of the consumption function. Thus, the next step is to explore whether the effect of wealth on consumption and saving varies with age, as suggested by the life-cycle model. We divide the age distribution into six groups $(24-34,35-44,45-54,55-64,65-74,75+)$ and then eleven groups (24$29,30-34,35-39,40-44,45-49,50-54,55-59,60-64,65-69,70-74,75+)$ and construct bivariate variables $\left(A_{i}\right)$ for each age group. The following specification allows for both, a differential effect of wealth and income on consumption by age groups, and a potential nonlinear effect of housing and financial wealth on consumption:

$$
\log C=\sum_{i=0}^{N}\left[\alpha_{i} \log F W * A_{i}+\beta_{i} \log H W * A_{i}+\delta_{i} \log Y * A_{i}\right]+\sum_{i=1}^{N} \varphi_{i} A_{i}+\sum_{j=0}^{J} \gamma_{j} O_{j} .
$$

\footnotetext{
${ }^{2}$ Many studies tend to focus on nondurable consumption, because conventional consumption theories apply to the flow of consumption. However, Mehra (2001) pointed out that total consumption ought to be used for investigating the link between consumption and wealth: stock market crashes are more likely to cause a delay in durable consumption while the fall in nondurable consumption might be negligible (see Romer 1990).
} 
In equation (2), $\alpha_{i}$ and $\beta_{i}$ represent the effects of financial and housing wealth, respectively, on consumption for households whose head is in the ' $i$ ' age group, and ' $N$ ' is the total number of age groups.

The above regressions allow us to test for existing age differences within countries. In a panel analysis we would be able to control for time and cohort effects, thus singling out pure (wealth) age effects, which, according to the life-cycle model, should increase with age. Having only cross-sectional data at our disposal, we limit our analysis to stating the differences across ages at a given point in time and comparing those across countries. ${ }^{3}$

In the next step, we compare the wealth effects between countries. Then, in a pooled cross section with interaction terms, we determine whether the existing within-country differences are significantly different across countries by differencing out country-specific effects (believed to be for example, institutional or cultural effects).

\subsection{Methodological Issues}

Housing wealth is observed only for homeowners, and so it may be argued that it is a nonrandom sample and we need to control for sample-selection bias. To address this concern, we estimate our model on the full sample and the sample of homeowners and find the results for the two wealth effects are not significantly different. ${ }^{4}$ Consequently, we only present estimation results for a subsample of homeowners. We also exclude households whose head is 24 years and younger from our analysis.

\footnotetext{
${ }^{3}$ In another paper, Sierminska and Takhtamanova (2007) also investigate differences in wealth effects by family type and gender.

${ }^{4}$ Estimates for full sample are available from authors upon request.
} 


\section{$4 \quad$ Data}

The data used in the analysis come from the Luxembourg Wealth Study (LWS), a new project that is under development within the larger Luxembourg Income Study (LIS). ${ }^{5}$ The LWS database contains comparable wealth data from nine industrialized countries, created for the purpose of conducting cross-country studies (see Sierminska 2005 and Sierminska et al.2006b, for a detailed description). The careful design of the LWS facilitates comparative research among wealth, income, and expenditure components. Based on the availability of expenditure data, we have chosen three countries for our analysis: Canada, Finland, and Italy. The original data sets that the LWS project harmonized include, for Canada, the Survey of Financial Security (SFS) 1999; for Finland, the Household Wealth Survey 1998; and for Italy, the Survey of Household Income and Wealth (SHIW) 2002.

Expenditures, our dependent variable, are created by summing the available expenditure components provided by the surveys. ${ }^{6}$ We include measures of wealth and income as explanatory variables. Wealth or net worth consists of financial assets and nonfinancial assets net of total debt. Financial assets include deposit accounts, stocks, bonds, and mutual funds. Nonfinancial assets include own principal residence and investment real estate. Total debt refers to all outstanding loans, both home-secured and non-home secured. Housing wealth refers to nonfinancial assets net of home-secured debt.

Our income concept refers to adjusted household disposable income. Disposable income is the sum of earnings, capital income, private transfers, public social insurance and public social assistance net of taxes and social security contributions. To avoid simultaneity issues we exclude capital income (Guiso et al. 2005), which includes interest and dividends, rental income, income

\footnotetext{
${ }^{5}$ Information on LWS can be found at http://www.lisproject.org/lws.htm.

${ }^{6}$ A detailed description of the variables is in Appendix B.
} 
from savings plans (including annuities from life insurance and individual private pensions), royalties, and other property income. ${ }^{7}$

In the analysis that follows, all monetary terms are reported at the household level. In income literature, it is standard to adjust income to account for household size by equivalizing the data. There is no such standard in the wealth literature and approaches vary, although results do not (Sierminska and Smeeding 2005). Nevertheless, we equivalize all monetary variables as follows: the adjusted variable equals the unadjusted variable divided by the square root of the household size. The use of the square root implies assuming an equivalency elasticity of .5 (Buhmann et al. 1988) and this is the middle point between two theoretical possibilities: no economies of scale and perfect economies of scale within the household.

For comparability, monetary variables are converted to 2002 U.S. dollars by using the 2002 OECD purchasing power paricy (PPP) exchange rates and OECD price indices. Specifically, country price indices are used to express the variables in 2002 values of own currency, then the country variables are divided by the country's PPP to eliminate the difference in price levels between the country and the U.S.

The household sample characteristics are in Table 1. The Italian sample on average is the oldest, and has the highest housing wealth holdings, lowest income and low financial wealth compared to the other two countries. The Canadian sample has the highest income, employment, and financial wealth. Finland has the highest fraction of households investing in risky assets (stocks) and the lowest wealth regardless of its type.

It is notable that in all countries in the sample the majority of wealth is held in the principal residence (Table 2). Certain cross-country differences also stand out. The three

\footnotetext{
${ }^{7}$ Capital income does not include capital gains and losses, which are both excluded from the concept of DPI. Imputed rent, and irregular incomes such as lottery winnings and any other lump-sums are also excluded from the concept of DPI. See Niskanen (2006) for the exact definition of DPI in LWS.
} 
countries under consideration have a much higher share of assets in nonfinancial wealth and in primary residence than the U.S. Another notable observation is that Italy has remarkably low debt, which is a reflection of the mortgage market in Italy (for further discussion of the Italian mortgage market, see Grant and Peltonen 2005 and Catte et al. 2004). Although in Finland the largest percent of households invests in risky assets (as shown in Table 1), this does not translate into a large fraction of their overall wealth portfolio, as financial assets represent 16 percent of overall assets in Finland and stocks represent only 6 percent. In comparison, in the United States, 45 percent of wealth is held in the principal residence and 38 percent in financial asset accounts with stocks accounting for 15 percent of total assets. Canadians and Europeans not only hold a relatively greater percentage of their wealth in real estate but also have smaller financial holdings (Sierminska et al. 2006a).

\section{$5 \quad$ Empirical Analysis}

\subsection{Financial and housing wealth effects across countries}

To underpin differences in overall financial and housing wealth effect, we estimate three specifications of equation (1) for each country. ${ }^{8}$ Estimation results for total expenditures as a dependent variable are presented in Table 3. First, we exclude all the demographic and location variables from the list of explanatory variables and focus on the two measures of wealth and income. This specification is close to the consumption function derived from the simplest version of the life-cycle model. The estimation results for the baseline specification are presented in column (1) of Table 3 for each of the three countries under consideration. Second, we include all the demographic and location variables we have, as well as dummies for net worth

\footnotetext{
${ }^{8}$ Standard errors have been corrected for heteroskedasticity using White's (1980) estimator of the covariance matrix.
} 
quartiles to account for the heterogeneity in consumption behavior of households with different sociodemographic characteristics, location, and net worth. We exclude income in this specification to determine its impact on the wealth effect. Estimation results are presented in the second column of Table 3. Last, we estimate the equation with all the controls available and report the results in the third column of the table.

Estimation results reveal that both current income and demographic variables are important determinants of consumption. In terms of demographic variables, several interesting facts emerge. Consumption falls with age — the coefficients on the dummy for subsequent age groups decrease and are statistically significant for older age groups. Thus, on average, each age group spends less than the next younger group. This result is true for all countries in the sample, but coefficients are only significant for older age groups in Finland and Italy.

We also find that, on average, households belonging to a higher wealth quartile spend less than the previous group. This result is true for every country. The coefficients on net worth quartile dummies are negative and statistically significant.

Education level is another important determinant of expenditures for all countries in that consumption expenditures rise with education. Education may serve as a proxy for permanent income suggesting that households with higher permanent income have higher consumption expenditures.

Having children matters;; our estimation results suggest that having older children (ages 5-18) has a significant negative effect on expenditures in Canada and Italy. Having younger children (under 5 years old) has a significant positive effect on expenditures in Canada and a negative effect in Italy. Being a parent, regardless of the age of the child, has a significant 
negative effect on expenditures in Canada and Finland, but no conclusive statement can be made about Italy — the results for this country are not robust with respect to equation specification.

Next we turn to marital status. Married couples spend more than the average household in Finland and less than the average household in Canada. No conclusive results on the link between marital status and consumption are revealed for Italy — the effect of marital status on consumption is positive, but the significance of this result depends on equation specification. Being employed also raises one's consumption in all three countries.

Table 3 shows that the wealth effect out of financial wealth is below that for housing wealth. According to the specification with a complete set of controls (column 3 in Table 3), consumption elasticity with respect to financial wealth is negligible in Canada, is about 0.02 in Finland, and is 0.04 in Italy. The housing wealth effect is much stronger. A 1 percent increase in household housing wealth raises household expenditures by about 12 percent in Canada, 10 percent in Finland and 13 percent in Italy (see column 3 for each country).

Our findings are in line with existing empirical evidence on wealth effects out of different types of wealth. In terms of microeconomic evidence, Guiso et al. (2005) find that, for a sample of homeowners, MPC out of financial wealth is below that out of housing wealth. Bostic et al. (2005) find this to be true for the U.S. as well. We are not aware of any micro studies on wealth effects in Finland. As for the macroeconomic evidence, Pichette and Tremblay (2003) use aggregate data for Canada and find that financial wealth has a very weak effect on consumption, while the housing wealth effect is large and significant. Another study that is also comparable to ours is Case et al.. (2005). The study uses aggregate data for a panel of 14 OECD countries and finds consumption elasticity with respect to financial wealth to be around zero and consumption elasticity with respect to housing wealth to be in the $0.11-0.17$ percent range. 
The inclusion of sociodemographic control variables is of greatest importance in Canada. Income elasticity of consumption is around 20 percent in Canada and Finland and about twice as large in Italy. Another result worth noting is that portfolio riskiness (measured as the ratio of stock holdings to bond holdings) has a positive and statistically significant effect on consumption for all the countries investigated.

The fact that housing wealth consumption elasticity is higher than financial wealth consumption elasticity holds with respect to different expenditure measures. Appendix Table C.2 shows elasticities of nondurable expenditures for Finland and Italy (no data on nondurables is available for Canada). Elasticity of consumption with respect to different types of wealth is lower for non-durables than it is for total expenditures, whereas income elasticity of consumption is fairly similar for both expenditure types.

Table 3 lends insight into differences in wealth effects by type and across countries. In the next step, we explore within-country differences in the wealth effects across age groups.

\subsection{Within- and between-country wealth effects by age}

Our initial specification does not allow for nonlinearities in the wealth effect by age groups. Thus, as the next step, we estimate equation (2). This equation specification includes all control variables (the same as in column 3 of Table 3). We begin our discussion of the age wealth effect by focusing on within-country age differences. In our later discussion we will discuss between-country differences.

At first, we consider six age groups $(25-34,35-44,45-54,55-64,65-74,75+)$. Our estimation results are presented in Appendix C (table C.3). For this discussion of within-country age differences, columns 2, 4 and 6 (shaded columns) are of interest. Figure 1 is a graphical 
representation of these results, and we focus our discussion on this figure. The labels show the numerical value of coefficient estimates, and the shading indicates statistical significance of at least a 10 percent level.

The financial wealth effect is for the most part smaller than the housing wealth effect at all ages with one exception: the 25-34 Finnish households. There is no clear pattern in the financial wealth effects for different age groups for Canada and Finland. In Canada it is negative and small for the middle-aged (35-64) and not statistically significant for other age groups. In Finland it is positive and small, but not statistically significant for any age group. In Italy, it is the largest and, although not monotonically, it increases with age.

A much clearer pattern emerges for the housing wealth effect. For all three countries, the housing wealth effect is significantly lower for younger households, which is consistent with the predictions of the life-cycle hypothesis.. The lowest effect is observed for those 25-34 in Italy and Finland, and for those 35-44 in Canada. The housing wealth effect is the strongest for those 55-64 in Finland and Italy and those 75 and over in Canada. In Canada the effect increases as we move to older groups from 55 onwards, and in Finland and Italy the effect increases up to the 5564 group and then is lower in the two oldest age groups.

The income effect by age group is presented in Appendix Table C.3 and shown graphically in Figure 3. In Canada, it is most pronounced and declines with age (Bostic et al. 2005 and Grant and Peltonen 2005 also find elevated income elasticities for younger age groups in the U.S. and Italy respectively $\left.{ }^{9}\right)$. There is no such clear pattern in Finland and Italy. For all countries, the income effect is stronger than the housing effect, with the exception of the oldest group in Canada.

\footnotetext{
${ }^{9}$ One explanation for higher income elasticity of the younger age groups is that they are more likely to be credit constrained.
} 
Next, we split the age distribution into finer age groups to gain some insight into differences in the wealth effect, particularly for the younger and older age groups. Estimation results are presented in Table 4 (only shaded columns are relevant for this discussion). For discussion we refer to the coefficient plots that are found in Figure 2a and $2 b$.

For the most part, looking at finer age groups gives us little additional insight into the financial wealth effect with some minor exceptions. In Canada the effect is positive only for the very young (25-29 age group) and not for the 30-34 group (thus, it is the 30-34 age group that "pulls" the financial wealth effect estimate for 25-34 group below zero, as shown in Figure 1). It is also positive for those 75 and older, although as before, it is still very close to zero. In Finland, we now have one age group for which the financial wealth effect is significant - those between 70 and 74. In Italy, a curious shift occurs. The disaggregated effect is positive for the very young, is negative and significant for the $30-34$ group (unlike before), and is significantly lower from the effect of the 55 to 69 -year-olds and those 75 and over.

The housing effect with the finer age groups shows a lot more variation by age, although the main result stands: the wealth effect is significantly higher at older ages than for the young or very young. These markedly different wealth effects occur at different stages across countries. In Canada, the effect for those 60 and older is significantly higher than for those younger than 50 . In Finland, the effect for those 55 and older is higher than for those less than 30, but not always significantly. In Italy, the effect for those 45 and over is significantly higher than for those 30 and younger. The effect is strongest for those 55-59 and is systematically smaller for the older age groups.

Our finding that the consumption elasticity for housing wealth increases with age, peaks at a certain age (likely to be an age close to retirement), and then subsides is similar to Lehnert's 
(2004) findings for the U.S. Lehnert separates his sample into age quintiles and finds the highest consumption sensitivity to house price shocks at the fourth quintile (those aged 52 to 62). Our results for the younger age groups are notably different from Lehnert's, though. Lehnert finds that elasticity for the youngest quintile is higher than for the next two older quintiles. This is definitely not the case for the three countries in our sample. Whether we can conclude that consumption behavior of younger households in the U.S. and the three countries we investigate is different is not entirely clear, as there seems to be no consensus on housing wealth effects for the young in the U.S. Bostic et al. 2005, using U.S. data, find results similar to ours — damped wealth elasticities and elevated income elasticities among younger households (25-35) as compared to older ones.

We now turn to between-country comparisons. We look at three pair-wise comparisons as shown in Table 4. The second column shows differences between Italy and Finland, the fourth column presents differences between Finland and Canada, and the last column reports differences between Canada and Italy.

Significant country differences in the financial wealth effect exist in all countries for one age group - those between 55 and 59 (see Table 4a). Canada and Italy exhibit differences virtually at all ages. Italy and Finland exhibit the fewest differences.

We see fewer cross-country differences in the housing wealth effect (see Table 4a). In fact, we do not find any country differences between Italy and Finland. Between Canada and the other two countries, differences exist for the middle aged 55-59 group and those over 75. In Canada and Italy differences also exist for younger individuals up to the age of 40 .

For the income effect (see Table 4b), differences between Italy and Finland exist for the middle-aged and those aged 70 and over; in Canada and Italy for those 50 and over; and in 
Finland and Canada for those 40-44 and 65-69. Once again the country effect is present for the middle-aged.

An interesting direction for future research would be to look for explanations for these cross-country differences. Looking at institutional differences among the countries under consideration appears to be a reasonable step to take. Explaining cross-country differences, however, is beyond the scope of this paper.

\section{$6 \quad$ Summary and Conclusions}

This study presents empirical evidence supporting the claim that the wealth effect out of housing wealth is different from that out of financial wealth. We find that the overall wealth effect out of housing is stronger than the effect out of financial wealth for all the countries in our sample. Although our results are significant, it is possible that the housing wealth has a large wealth effect because it serves as a proxy for permanent income, which is an important determinant of household consumption. On the other hand, our estimates are broadly consistent with some studies using microdata (Bostic et al. 2005 for U.S. and Guiso et al. 2005 for Italy). Moreover, we make an extensive effort to control for permanent income by including a variety of sociodemographic characteristics of the household.

Results point to within- and between-country differences in wealth effects. In accordance with economic theory, we find significant wealth effect differences across age groups within each country. Our analysis bolsters other studies by finding evidence that the housing wealth effect is consistently stronger for older households for a set of three countries. In our investigation, we find that the effect is strongest for the oldest group in Canada and the late middle-aged groups in Finland and Italy. 
We also find between-country differences in the wealth effects. Significant differences between countries in the financial wealth effect exist in all countries for the young, the middleaged around the age of retirement, and the very old in Canada and Italy. For the housing wealth effect, no significant differences among age groups exist for Italy and Finland. However, there are differences for Finland and Canada and for Canada and Italy for the middle-aged 55-59 age group and for those over 75. Additionally, in Canada and Italy differences also exist for younger individuals up to the age of 40 . A fruitful venue for future research would be to to investigate some of the causes of these differences.

Our findings suggest that it is important for policymakers to keep an eye on housing market developments separately from financial markets. If it is true that the housing wealth effect dominates the financial wealth effect, at least in some countries, then the effects of a softening in the housing market in a number of industrialized countries could have effects more dramatic than the historic stock market declines that began in 2000. Additionally, if the wealth effect is stronger for older households, the demographic changes around the world could make housing wealth effects even more important in the future.

\section{References:}

Ando, A. and F. Modigliani. 1963. "The Life-Cycle Hypothesis of Saving: Aggregate Implications and Tests." American Economic Review, 53(1), p. 55-84.

Belsky, Eric and J. Prakken. 2004. "Housing's Impact on Wealth Accumulation, Wealth Distribution and Consumer Spending." Joint Center for Housing Studies Working Paper W0413. http://www.jchs.harvard.edu/publications/finance/w04-13.pdf

Boone, Laurence and N. Girouard. 2002. "The Stock Market, the Housing Market and Consumer Behavior." OECD Economic Studies, No. 35, 2002/2. 
Bostic, R., S. Gabriel, and G. Painter. 2005. "Housing Wealth, Financial Wealth and Consumption: New Evidence from Micro Data." The Lusk Center for Real Estate Working Paper 2004-1005. http://www.usc.edu/schools/sppd/lusk/research/pdf/wp_2004-1005.pdf

Bover, O. 2005. "Wealth Effects on Consumption: Microeconometric Estimates from the Spanish Survey of Household Finances," Documentos de Trabajo, No. 0522, Banco de Espana, Spain.

Buhmann, B., L. Rainwater, G. Schmaus and T. Smeeding. 1988. "Equivalence scales, wellbeing, inequality, and poverty: sensitivity of estimates across ten countries using the Luxembourg Income Study (LIS) database," Review of Income and Wealth, 34 (2), 115-142.

Campbell, J. Y. and J. F. Cocco. 2005. "How do House Prices Affect Consumption? Evidence from Micro data." NBER Working Paper 11534.

Carroll, C. 2004. "Housing Wealth and Consumption Expenditure." Unpublished manuscript, Johns Hopkins University.

Case, K., J. Quigley, R. Shiller. 2005. "Comparing Wealth Effects: The Stock Market versus the Housing Market." Advances in Macroeconomics: Vol. 15: no. 1, article 1.

http://www.bepress.com/cgi/viewcontent.cgi?article=1235\&context=bejm.

Catte, P., N. Girouard, R. Price, and C. André. 2004. "Housing Market, Wealth and the Business Cycle," Working paper 17, OECD.

Davis, M., and M. Palumbo. 2001. "A Primer on the Economics and Time Series Econometrics of Wealth Effects." Federal Reserve Board. Finance and Economics Discussion Paper No. 2001-09.

Disney, R., A. Henley, and D. Jevons. 2003. "House Price Shocks, Negative Equity and Household Consumption in the U.K." Mimeo, University of Nottingham.

Dolmas, J. 2003. "A Note on the Potential Pitfalls in Estimating a 'Wealth Effect' on Consumption from Aggregate Data." Economic Letters, 78(3), p. 437-44.

Dvornak, N., and M. Kohler. 2003. "Housing Wealth, Stock Market Wealth and Consumption: A Panel Analysis for Australia." Reserve Bank of Australia, Research Discussion Paper 2003-07.

Dynan, K. and D. Maki. 2001. “Does Stock Market Matter for Consumption?" FEDS Discussion Paper No. 2001-23 (May).

Friedman, Milton. 1957. “A Theory of the Consumption Function.” Princeton University Press, Princeton.

Goodman, A.C. and M. Kawai. 1982. "Permanent Income, Hedonic Prices and Demand for Housing: New Evidence.” Journal of Urban Economics, 12, 214-37. 
Gourinchas, Pierre-Olivier and Jonathan A. Parker. 2002. "Consumption Over Life Cycle." Econometrica. 70 (1), 47-89.

Grant, C. and T. Peltonen 2005. "Housing and Equity Wealth Effects of Italian Households." DNB Working Paper No. 43.

Guiso, L., M. Paiella and I. Visco 2005. "Do capital gains affect consumption? Estimates of wealth effects from Italian households' behavior" Temi di discussione No. 555 - June 2005

Hoynes, H., and D. McFadden. 1994. "The Impact of Demographics on Housing and NonHousing Wealth in the United States." NBER Working Paper 4666.

Hurd, M., and S. Rohwedder. 2005. "Changes in Consumption and Activities at Retirement." DNB Working Paper No. 39.

Lehnert, A. 2004. "Housing, Consumption, and Credit Constraints." Federal Reserve Board Working Paper No. 2004-63.

Ludwig, A. and T. Slok. 2004. "The Relationship Between Stock Prices, House Prices, and Consumption in OECD Countries." Berkeley Electronic Press, 4(1): 1114-1114.

Mehra, Y. 2001. "The Wealth Effect in Empirical Life-Cycle Aggregate Consumption Equations.” Federal Reserve Bank of Richmond Economic Quarterly 87 (2), 45-68.

Modigliani, F. and R. Brumberg. 1954. "Utility analysis and the consumption function: An interpretation of cross-section data." In: Kurihara, K.K (ed.): Post-Keynesian Economics.

Niskanen, E. 2006. "The Luxembourg Wealth Study: Technical Report on Income Variables," unpublished manuscript July 2006.

Pichette, L., and D. Tremblay. 2003. "Are Wealth Effects Important for Canada." Bank of Canada Working Paper 2003-30.

Poterba J., and A. Samwick. 1995. "Stock Ownership Patterns, Stock Market Fluctuations and Consumption." Brookings Papers on Economic Activity, 2: 295-372.

Romer, C. 1990. "The Great Crash and the Onset of the Great Depression." Quarterly Jounral of Economics 105: 597-624.

Shefrin, H. and R. Thaler. 1988. "The behavioral life-cycle hypothesis." Economic Inquiry, 26: 609-643.

Sierminska, E. 2005. "The Luxembourg Wealth Study: A Progress Report," paper prepared for LWS Workshop: "Construction and Usage of Comparable Microdata on Wealth: the LWS," Perugia, Italy, 27-29 January 2005. 
Sierminska, E. and T. Smeeding 2005. "Measurement Issues: Equivalence Scales, Accounting Framework and Reference Unit"," paper prepared for LWS Workshop: "Construction and Usage of Comparable Microdata on Wealth: the LWS,” Perugia, Italy, 27-29 January 2005.

Sierminska, E., Brandolini, A. and T. Smeeding 2006a. "Comparing wealth distribution across rich countries: First results from the Luxembourg Wealth Study" Luxembourg Wealth Study Working Paper No. 1, August 2006.

Sierminska, E., Brandolini, A. and T. Smeeding 2006b. "The Luxembourg Wealth Study- A cross-country comparable database for household wealth research" Journal of Economic Inequality, 4(3): 375-383, 2006.

Sierminska, E., and Y. Takhtamanova 2007. "The Effect of Wealth on Consumption Expenditures: Cross-Country and Cross Socio-Demographic Group Comparisons" Ekonomia (forthcoming), 2007.

Venti, S., and D. Wise. 2001. "Aging and Housing Equity: Another Look." NBER Working Paper 8608.

White, H. 1980. "A heteroskedasticity-consistent covariance matrix estimator and a direct test for heteroskedasticity." Econometrica, 48, 4, 817-838. 
Figure 1. Financial and housing wealth effect for six age groups.

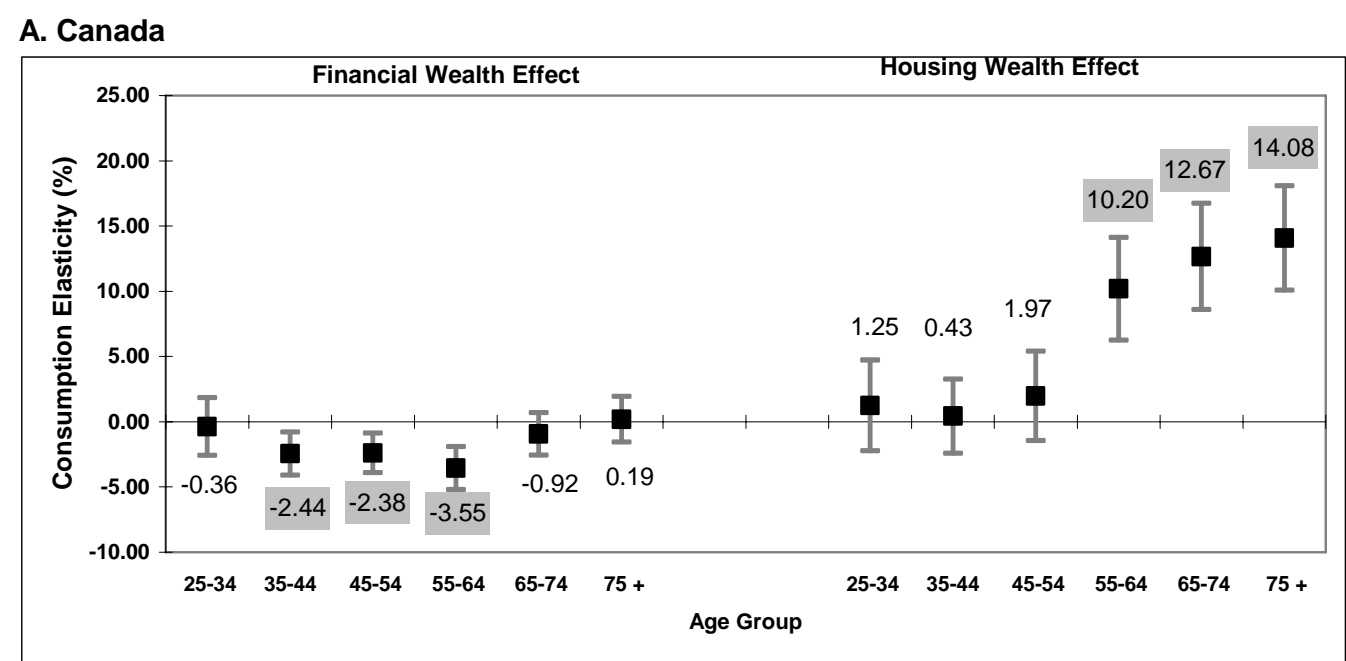

\section{B. Finland}

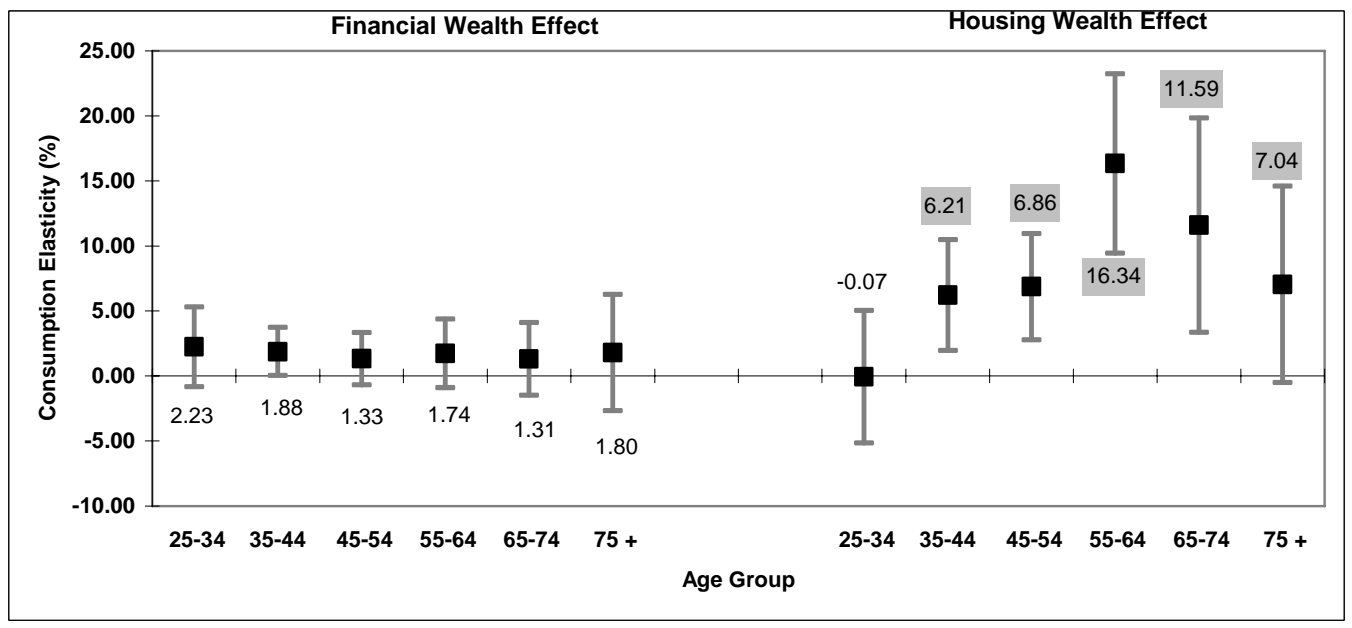

\section{Italy}

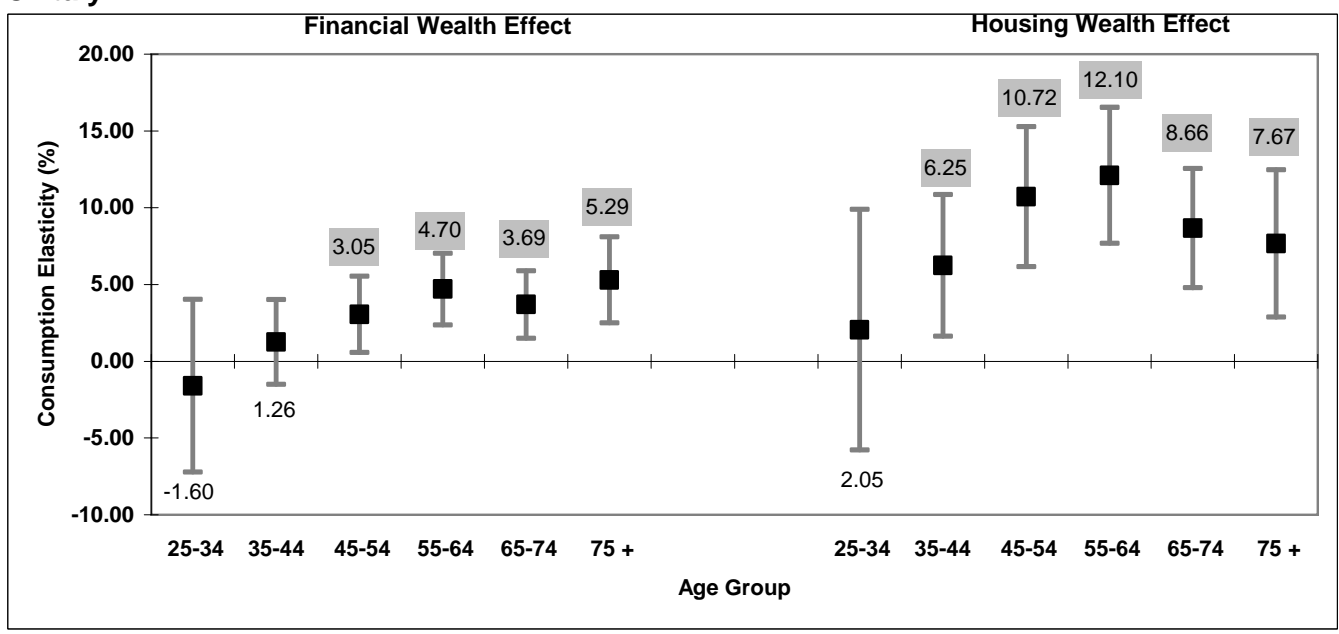

Note: Shaded results indicate significance of at least $10 \%$. 
Figure 2a. Financial wealth effect for eleven age groups.

A. Canada

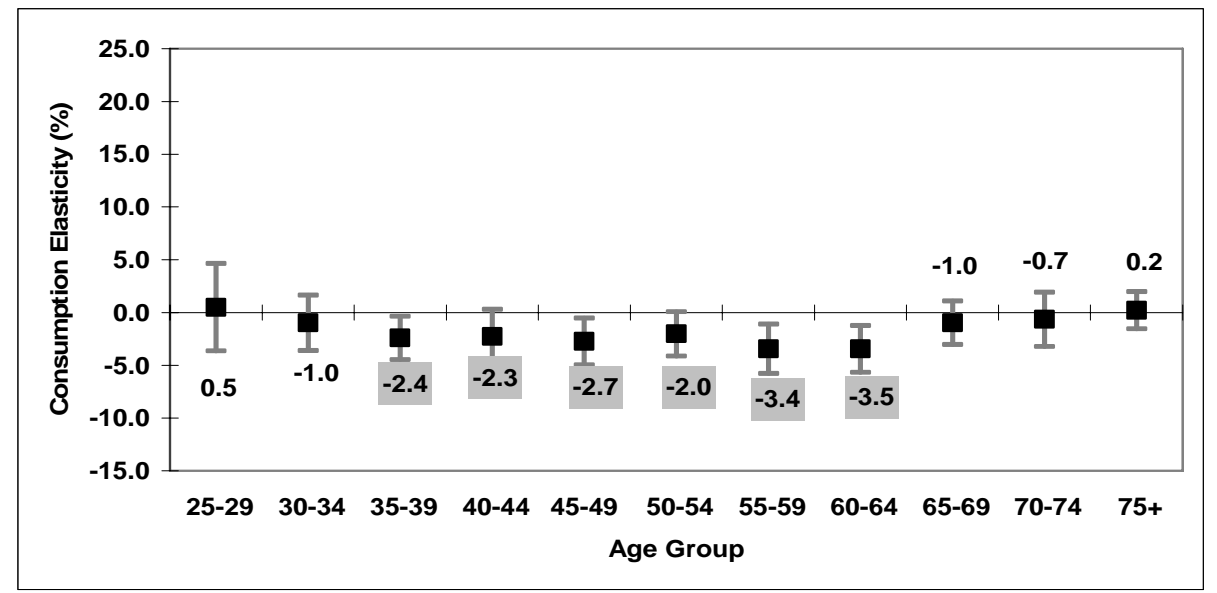

\section{B. Finland}

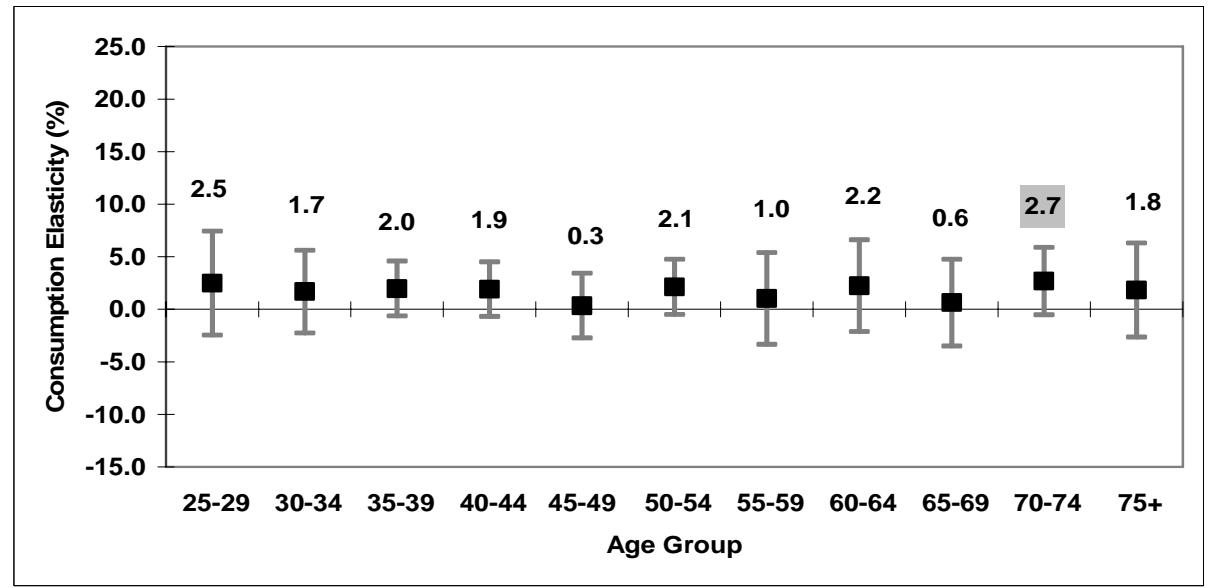

C. Italy

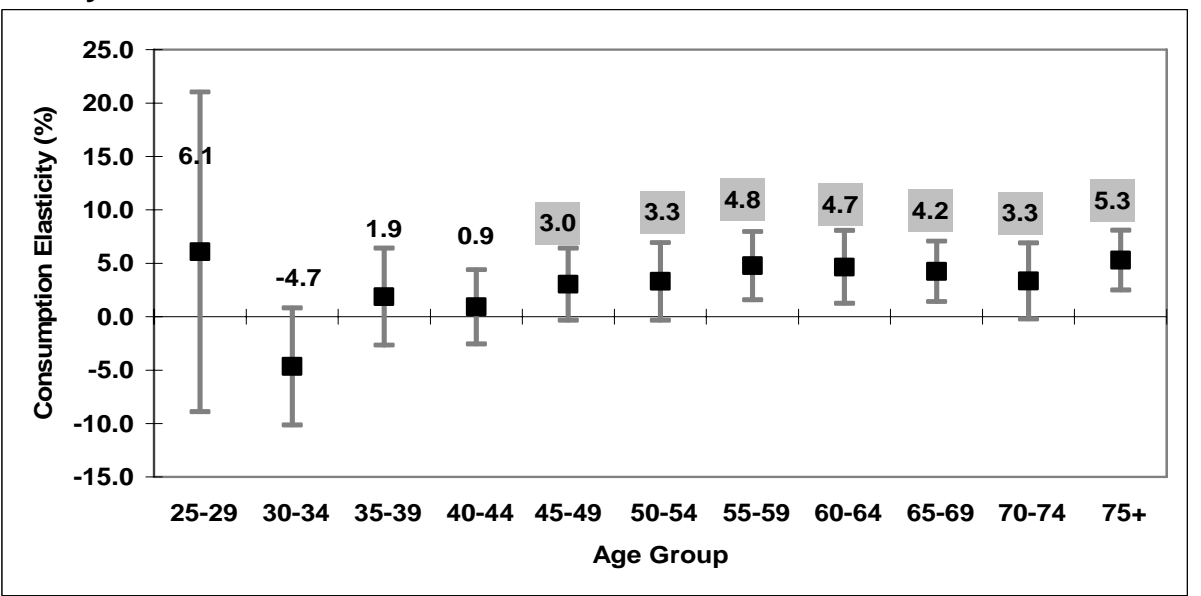

Note: Shaded results indicate significance of at least $10 \%$ 
Figure $2 \mathrm{~b}$. Housing wealth effect for eleven age groups.

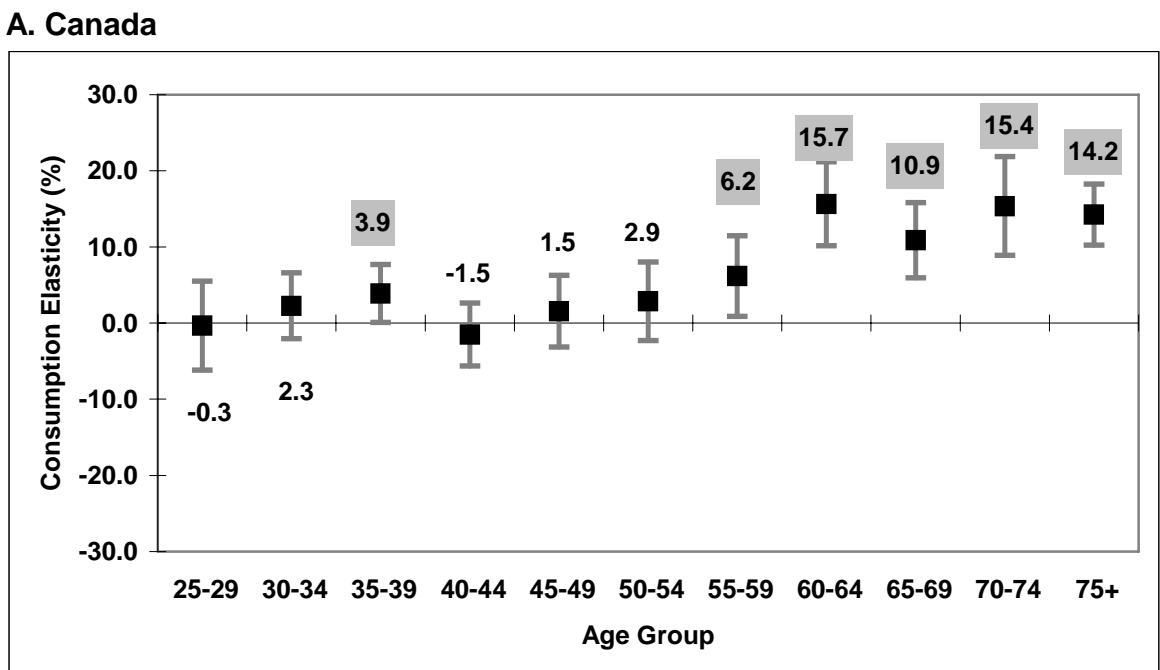

B. Finland

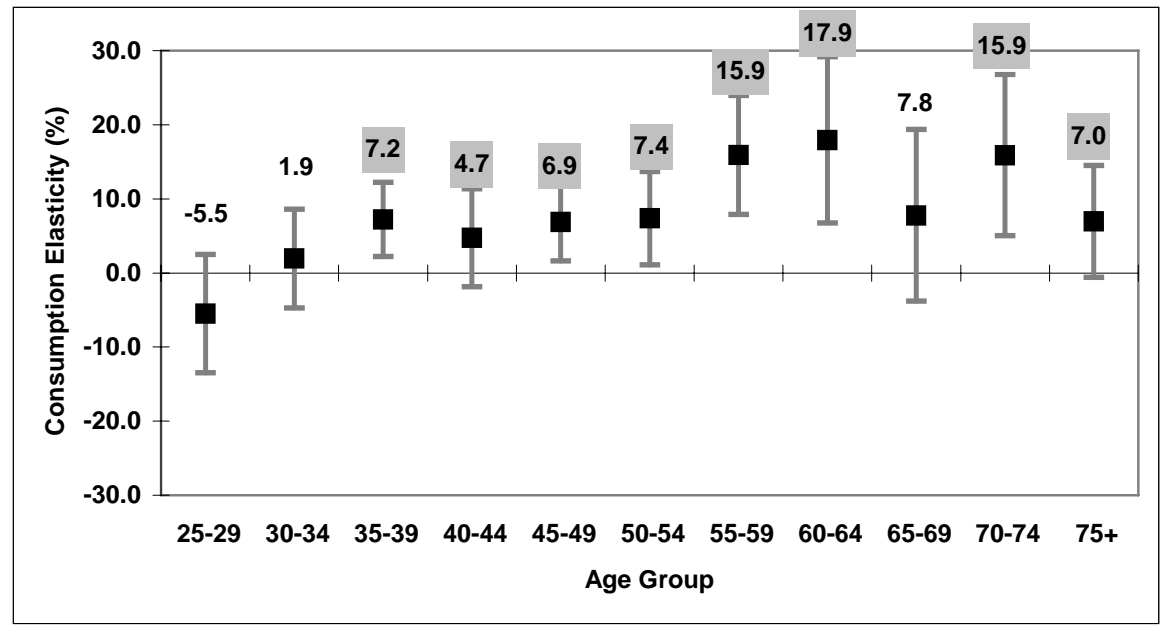

C. Italy

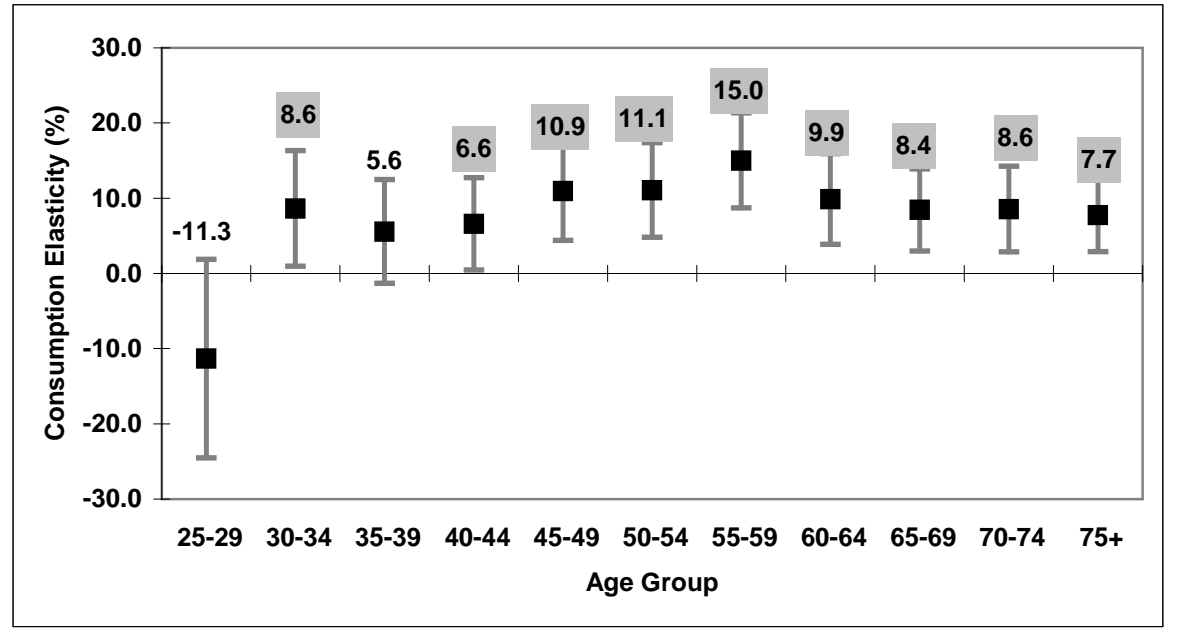

Note: Shaded results indicate significance of at least $10 \%$ 
Figure 3 Income Effect.

\section{A. Canada}

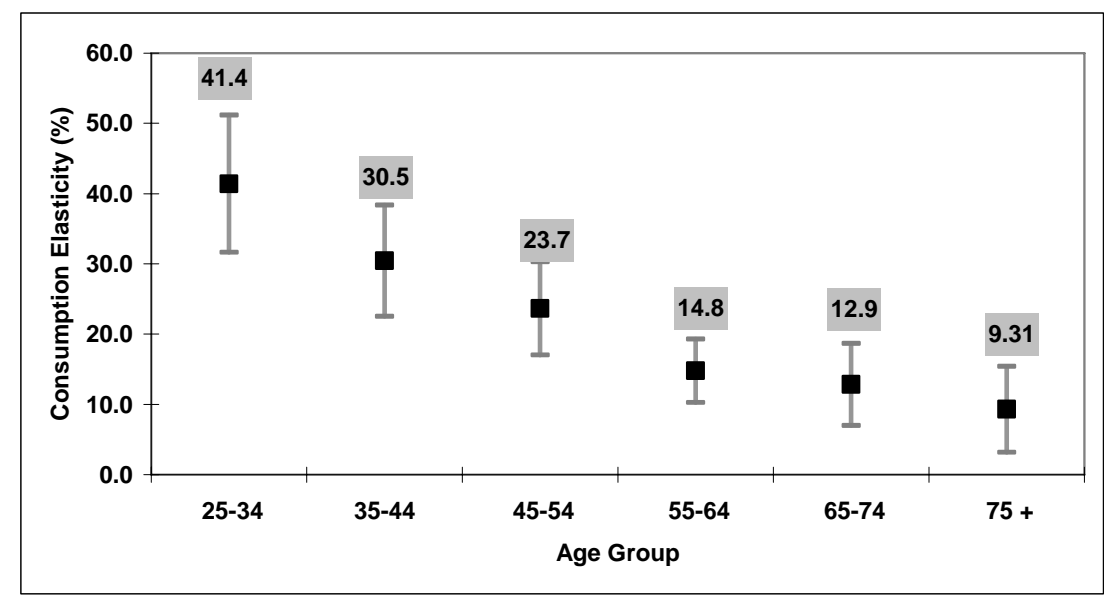

B. Finland

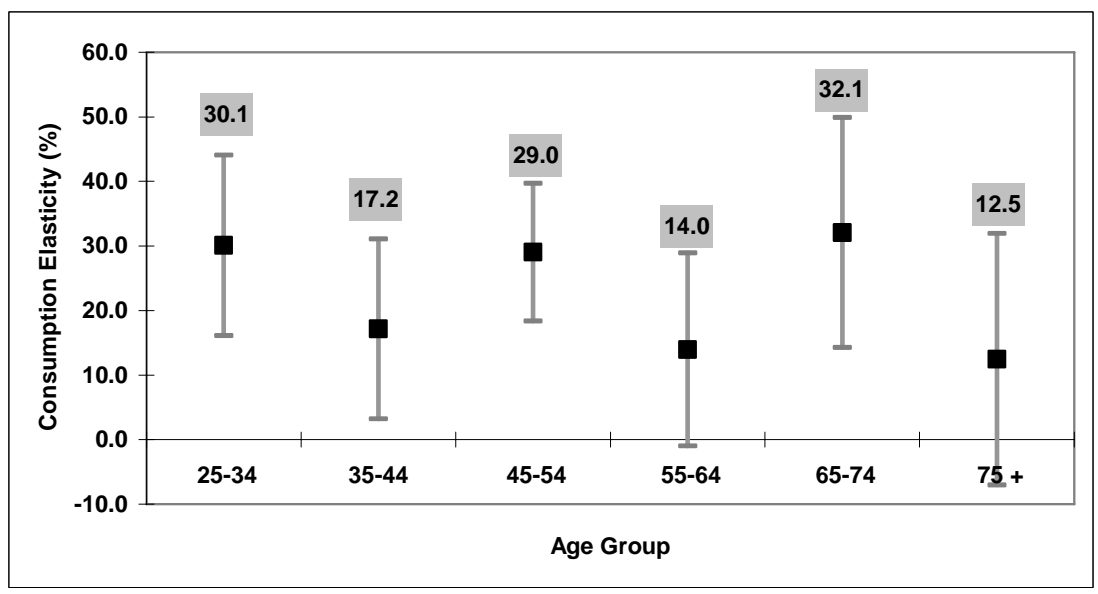

\section{Italy}

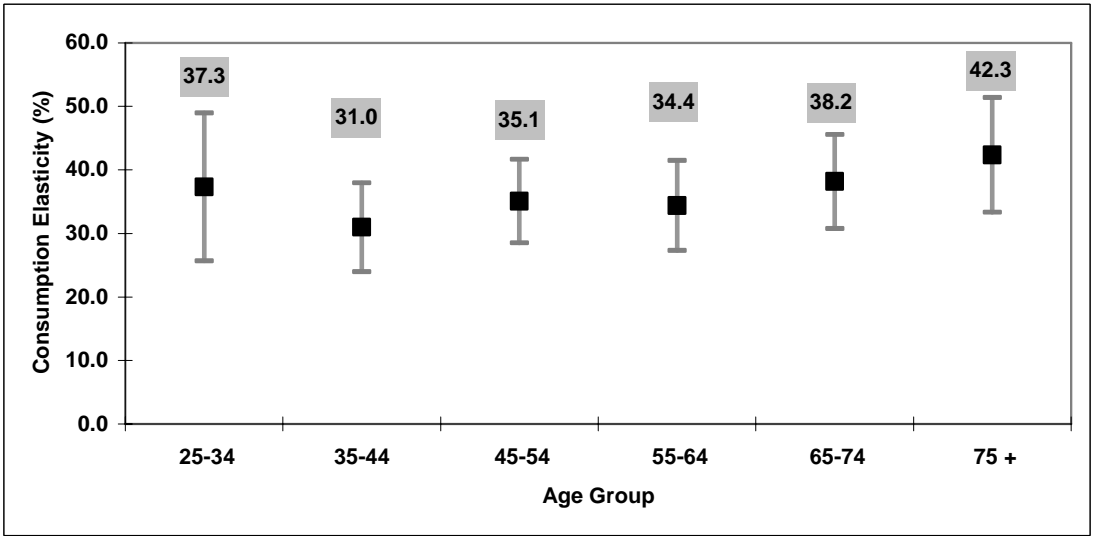

Note: Shaded results indicate significance of at least $10 \%$ 
Table 1. Household characteristics by country.

\begin{tabular}{|c|c|c|c|}
\hline & Canada & Finland & Italy \\
\hline & 1999 & 1998 & 2002 \\
\hline Male head of household & & 0.67 & 0.63 \\
\hline Age & 48.63 & 47.33 & 56.75 \\
\hline \multicolumn{4}{|l|}{ Age Groups: } \\
\hline Below 24 & 0.04 & 0.04 & 0.01 \\
\hline 24-34 & 0.18 & 0.17 & 0.07 \\
\hline $35-44$ & 0.24 & 0.24 & 0.17 \\
\hline $45-54$ & 0.20 & 0.27 & 0.20 \\
\hline $55-64$ & 0.13 & 0.16 & 0.20 \\
\hline $65-74$ & 0.12 & 0.08 & 0.19 \\
\hline $75+$ & 0.10 & 0.05 & 0.15 \\
\hline \multicolumn{4}{|l|}{ Education } \\
\hline Less than High School & 0.28 & 0.31 & 0.65 \\
\hline High School & 0.49 & 0.52 & 0.27 \\
\hline Bachelor's Degree & 0.23 & 0.17 & 0.08 \\
\hline Children under 18 & 0.35 & 0.34 & 0.25 \\
\hline Married & 0.62 & 0.72 & 0.66 \\
\hline Parents & 0.41 & 0.49 & 0.45 \\
\hline Employed & 0.76 & 0.71 & 0.44 \\
\hline Income & $\$ 26,588$ & $\$ 16,251$ & $\$ 13,686$ \\
\hline Financial wealth & $\$ 32,414$ & $\$ 13,291$ & $\$ 18,908$ \\
\hline Housing equity & $\$ 59,970$ & $\$ 57,668$ & $\$ 105,982$ \\
\hline Risk & 0.07 & 0.19 & 0.04 \\
\hline Sample Size & 14475 & 3780 & 8011 \\
\hline
\end{tabular}

Source: Authors' calculations based on the Luxembourg Wealth Study (LWS). Monetary variables are equivalized and valued in 2002 US dollars. 
Table 2. Household portfolio composition (percentage share of total assets)

\begin{tabular}{|c|c|c|c|c|}
\hline Wealth components & $\begin{array}{c}\text { Canada } \\
1999\end{array}$ & $\begin{array}{c}\text { Finland } \\
1998\end{array}$ & $\begin{array}{l}\text { Italy } \\
2002\end{array}$ & $\begin{array}{c}\text { United } \\
\text { States } \\
2001\end{array}$ \\
\hline Financial assets & 22 & 16 & 15 & 38 \\
\hline Deposit accounts & 9 & 10 & 8 & 10 \\
\hline Bonds & 1 & 0 & 3 & 4 \\
\hline Stocks & 7 & 6 & 1 & 15 \\
\hline Mutual funds & 5 & 1 & 3 & 9 \\
\hline Nonfinancial assets & 78 & 84 & 85 & 62 \\
\hline Principal residence & 64 & 64 & 68 & 45 \\
\hline Investment real estate & 13 & 20 & 17 & 17 \\
\hline Total assets & 100 & 100 & 100 & 100 \\
\hline Total debt & 26 & 16 & 4 & 21 \\
\hline Home-secured debt & 22 & 11 & 2 & 18 \\
\hline Total net worth & 74 & 84 & 96 & 79 \\
\hline
\end{tabular}

Source: Sierminska et al. (2006a).

Note:Asset shares are computed as ratios of the averages. Household weights are used 
Table 3. OLS estimates of wealth effect for total expenditure. Dependent variable: total expenditure ${ }^{1}$

Robust Standard Errors in Parentheses

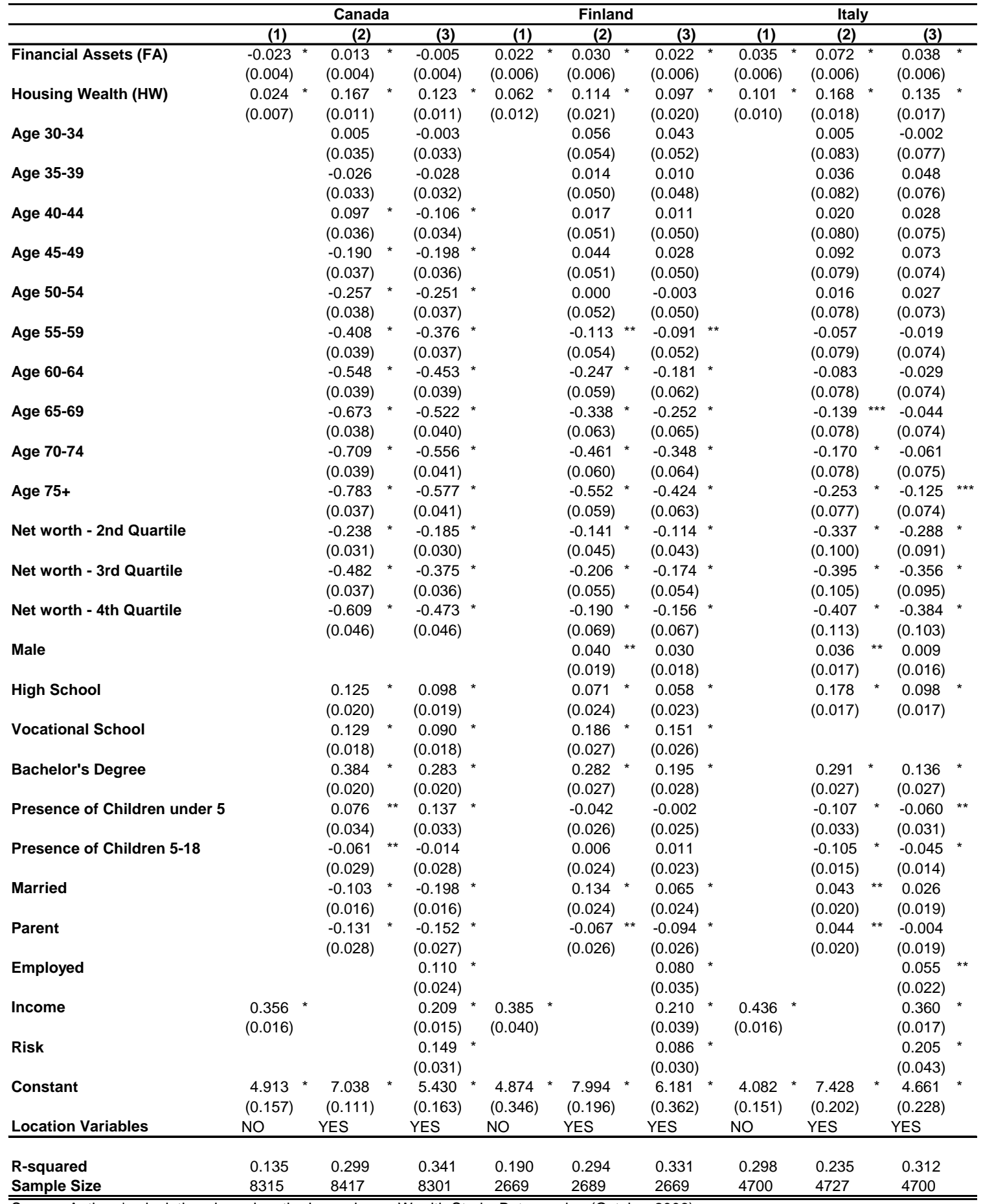

Source: Authors' calculations based on the Luxembourg Wealth Study, Beta-version (October 2006).

Note: Significance levels are ${ }^{*}-1 \%,{ }^{* *}-5 \%,{ }^{* * *}-10 \% ;{ }^{1}$ Variables are in logs 
Table 4a. Within- and between-country differences in the wealth effect across age groups.

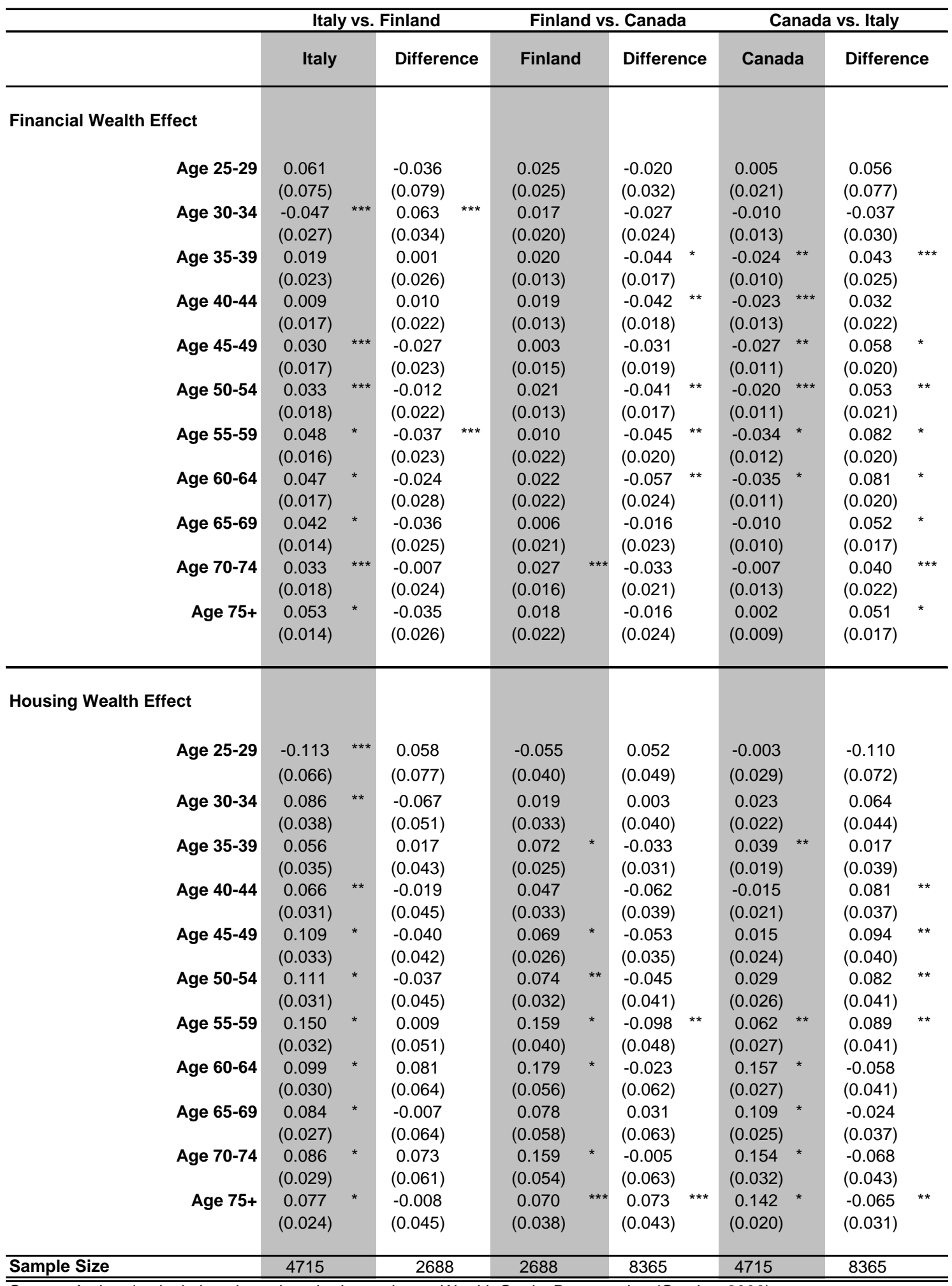

Source: Authors' calculations based on the Luxembourg Wealth Study, Beta-version (October 2006).

Note: Significance levels are ${ }^{*}-1 \%,{ }^{*}-5 \%,{ }^{* *}-10 \% ;{ }^{1}$ Variables are in logs. 
Table 4b. Within- and between-country differences in the income effect across age groups.

Dependent variable: total expenditure ${ }^{1} \quad$ Robust Standard Errors in Parentheses

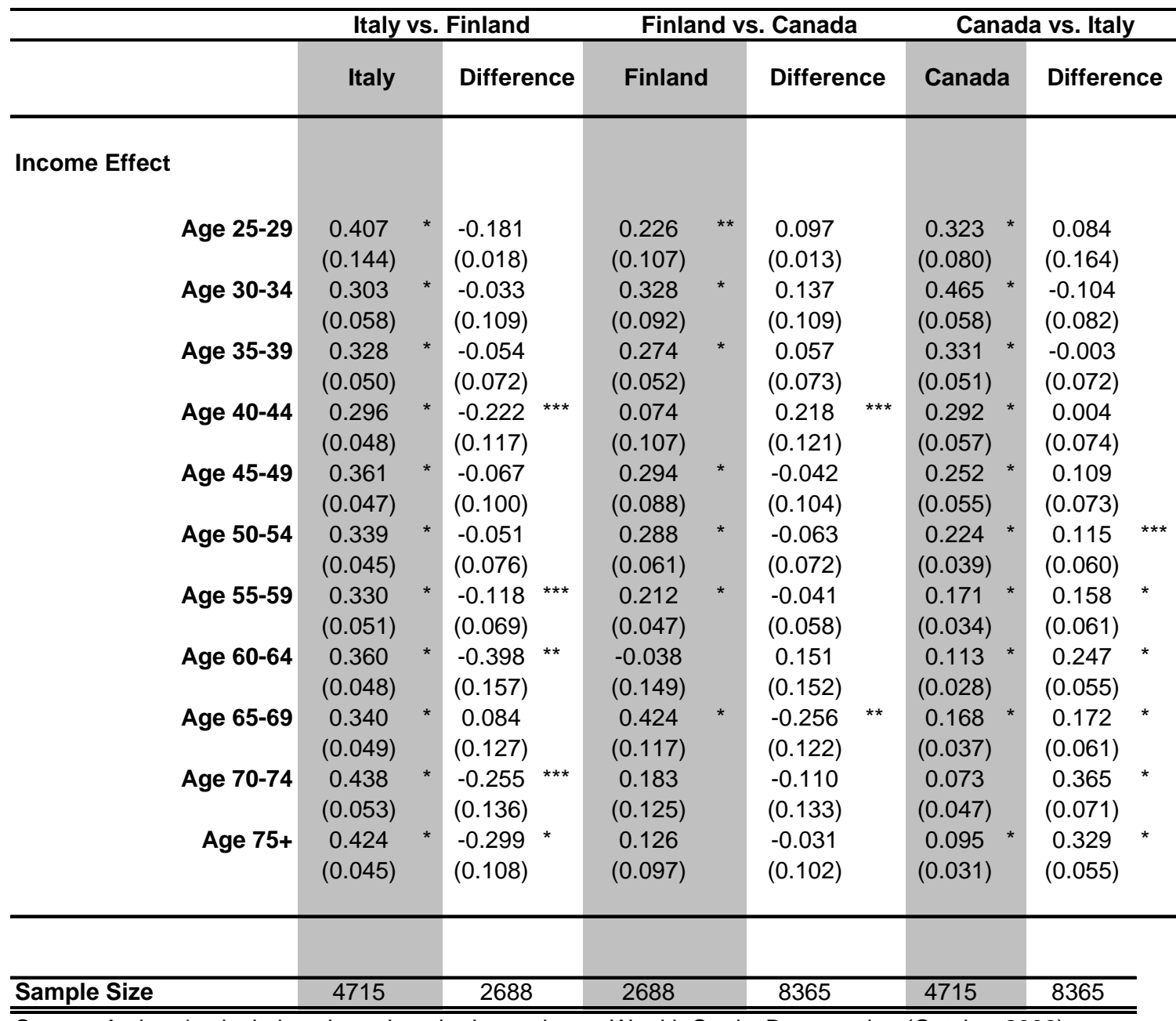

Source: Authors' calculations based on the Luxembourg Wealth Study, Beta-version (October 2006).

Note: Significance levels are ${ }^{*}-1 \%,{ }^{*}-5 \%,{ }^{* * *}-10 \% ;{ }^{1}$ Variables are in logs. 


\section{Appendix A.}

\section{Table A.1. Summary of selected empirical results.}

\begin{tabular}{|c|c|c|c|c|}
\hline \multirow[b]{2}{*}{ STUDY } & \multicolumn{4}{|c|}{ WEALTH } \\
\hline & PARAMETER & HOUSING & FINANCIAL & COUNTRY \\
\hline \multicolumn{5}{|c|}{ Aggregate Data } \\
\hline Davis \& Palumbo (2001) & L.R. MPC & 0.08 & 0.06 & U.S. \\
\hline Pichette \& Tremblay (2003) & L.R. MPC & 0.06 & 0 & Canada \\
\hline Carroll (2004) & L.R. MPC & 0.09 & 0.04 & U.S. \\
\hline Ludwig \& Slok (2004) & L.R. Elasticity & 0 & $0.023-0.052$ & $\begin{array}{c}\text { panel of } 16 \text { OECD } \\
\text { countries }\end{array}$ \\
\hline Case, Quigley \& Schiller (2005) & Elasticity & $0.11-0.17$ & 0 & $\begin{array}{c}\text { panel of } 14 \text { developed } \\
\text { countries }\end{array}$ \\
\hline \multicolumn{5}{|c|}{ State-Level Data } \\
\hline Dvornak \& Kohler (2003) & L.R.MPC & 0.03 & $0.06-0.09$ & Australia \\
\hline Case, Quigley \& Schiller (2005) & Elasticity & $0.05-0.09$ & 0.02 & U.S. \\
\hline \multicolumn{5}{|c|}{ Household-Level Data } \\
\hline Disney, Henley \& Jevons (2003) & MPC & $0.09-0.14$ & - & U.K. \\
\hline Campbell \& Cocco (2005) & Elasticity & 0.017 & - & U.K. \\
\hline Grant \& Pelton (2005) & MPC & 0.014 & 0.005 & Italy \\
\hline Lehnert (2004) & Elasticity & $0.04-0.05$ & - & U.S. \\
\hline Bostic, Gabriel \& Painter (2005) & Elasticity & 0.06 & 0.02 & U.S. \\
\hline Bover (2005) & MPC & 0.015 & - & Spain \\
\hline
\end{tabular}




\section{Appendix B. Variable Definitions.}

\section{Total Expenditures}

Canada: Total annual spending on housing, transportation, child care.

Finland: Total annual spending on housing, transportation, child care, food, utilities, medical, education, durables, other.

Italy: total annual spending on housing, food, durables, other

Durable Expenditures

Canada: not available.

Finland and Italy: Total annual spending on furnishing, household equipment/appliances, purchases of vehicles, equipment purchases, (e.g. telephones, mobiles, faxes, pagers.)

\section{Financial Assets}

The measure includes deposit accounts, stocks, bonds, and mutual funds.

Nonfinancial Assets

The sum of own principal residence and investment real estate

\section{Total Debt}

Includes all outstanding loans, both home-secured and non-home secured,

Housing Wealth

Computed as nonfinancial assets net of home-secured debt

\section{Income}

The sum of earnings, capital income, private transfers, public social insurance, public social assistance net of taxes and social security contributions.

Net worth $-i^{\text {th }}$ Quartile

A dummy variable taking a value of 1 if household's total wealth falls in the $i^{\text {th }}$ quartile and 0 otherwise.

\section{Male}

A dummy variable taking a value of 1 if household head is a male and 0 otherwise.

Education Variables (High School, Vacation School, Bachelor Degree)

A dummy variable taking a value of 1 if household head attained the specified level of education and 0 otherwise.

Presence of children $<=5$

A dummy variable taking a value of 1 if there are children 5 and younger in the household and 0 otherwise.

Presence of children 5-18 
A dummy variable taking a value of 1 if there are children of ages 5-18 years old in the household and 0 otherwise.

Married

A dummy variable taking a value of 1 if household head is married and 0 otherwise.

\section{Parent}

A dummy variable taking a value of 1 if household head has children (regardless of age) and 0 otherwise

\section{Employed}

A dummy variable taking on a value of 1 if household head is employed and 0 otherwise

Risk

Share of stock in financial assets

Location dummies

For each country, we also include a set of dummies that reflects household location. 


\section{Appendix C.}

Table C.1. Demographic characteristics for homeowners by country.

\begin{tabular}{|c|c|c|c|}
\hline & Canada & Finland & Italy \\
\hline & 1999 & 1998 & 2002 \\
\hline Male & & 0.70 & 0.65 \\
\hline Age & 51.31 & 49.57 & 57.88 \\
\hline \multicolumn{4}{|l|}{ Age Groups: } \\
\hline Below 24 & 0.01 & 0.01 & 0.00 \\
\hline 24-34 & 0.12 & 0.12 & 0.05 \\
\hline $35-44$ & 0.25 & 0.25 & 0.15 \\
\hline $45-54$ & 0.23 & 0.31 & 0.21 \\
\hline $55-64$ & 0.15 & 0.19 & 0.23 \\
\hline $65-74$ & 0.14 & 0.08 & 0.21 \\
\hline $75+$ & 0.10 & 0.05 & 0.15 \\
\hline \multicolumn{4}{|l|}{ Education } \\
\hline Less than High School & 0.26 & 0.32 & 0.62 \\
\hline High School & 0.48 & 0.50 & 0.29 \\
\hline Bachelor's Degree & 0.25 & 0.18 & 0.09 \\
\hline Children under 18 & 0.38 & 0.42 & 0.24 \\
\hline Married & 0.76 & 0.80 & 0.71 \\
\hline Parents & 0.46 & 0.54 & 0.47 \\
\hline Employed & 0.78 & 0.75 & 0.42 \\
\hline Income & 30,211 & 17,236 & 14,641 \\
\hline Financial wealth & 44,080 & 16,131 & 21,319 \\
\hline Housing equity & 89,999 & 74,287 & 149,733 \\
\hline Risk & 0.09 & 0.21 & 0.04 \\
\hline Sample Size & 9409 & 2884 & 5540 \\
\hline
\end{tabular}

Source: Authors' calculations based on the Luxembourg Wealth Study (LWS). Monetary variables are equivalized and valued in 2002 US dollars. 
Table C.2. OLS estimates of wealth effect of nondurable expenditure.

Dependent variable: nondurable expenditure ${ }^{1}$

Robust Standard Errors in Parentheses

\begin{tabular}{|c|c|c|c|c|c|c|c|c|c|c|}
\hline & \multicolumn{5}{|c|}{ Finland } & \multicolumn{5}{|c|}{ Italy } \\
\hline & (1) & (2) & & (3) & & (1) & $(2)$ & & (3) & \\
\hline Financial Assets (FA) & $\begin{array}{c}0.013 \\
(0.005)\end{array}$ & $\begin{array}{c}0.018 \\
(0.005)\end{array}$ & * & $\begin{array}{c}0.012 \\
(0.005)\end{array}$ & * & $\begin{array}{c}0.034 \\
(0.005)\end{array}$ & $\begin{array}{cc}* & 0.065 \\
& (0.006)\end{array}$ & * & $\begin{array}{c}0.034 \\
(0.005)\end{array}$ & * \\
\hline Housing Wealth (HW) & $\begin{array}{c}0.060 \\
(0.010)\end{array}$ & $\begin{array}{c}0.086 \\
(0.017)\end{array}$ & * & $\begin{array}{c}0.070 \\
(0.016)\end{array}$ & * & $\begin{array}{c}0.093 \\
(0.010)\end{array}$ & $\begin{array}{c}* \\
0.149 \\
(0.017)\end{array}$ & * & $\begin{array}{c}0.119 \\
(0.016)\end{array}$ & * \\
\hline Age $30-34$ & & $\begin{array}{c}0.030 \\
(0.045)\end{array}$ & & $\begin{array}{c}0.018 \\
(0.044)\end{array}$ & & & $\begin{array}{l}-0.023 \\
(0.077)\end{array}$ & & $\begin{array}{r}-0.0283 \\
(0.071)\end{array}$ & \\
\hline Age $35-39$ & & $\begin{array}{l}-0.010 \\
(0.042)\end{array}$ & & $\begin{array}{l}-0.013 \\
(0.041)\end{array}$ & & & $\begin{array}{c}0.036 \\
(0.076)\end{array}$ & & $\begin{array}{c}0.048 \\
(0.071)\end{array}$ & \\
\hline Age $40-44$ & & $\begin{array}{c}0.001 \\
(0.043)\end{array}$ & & $\begin{array}{l}-0.004 \\
(0.043)\end{array}$ & & & $\begin{array}{c}0.040 \\
(0.075)\end{array}$ & & $\begin{array}{c}0.049 \\
(0.069)\end{array}$ & \\
\hline Age 45-49 & & $\begin{array}{c}0.018 \\
(0.043)\end{array}$ & & $\begin{array}{c}0.000 \\
(0.042)\end{array}$ & & & $\begin{array}{c}0.103 \\
(0.074)\end{array}$ & & $\begin{array}{c}0.087 \\
(0.068)\end{array}$ & \\
\hline Age $50-54$ & & $\begin{array}{c}0.008 \\
(0.044)\end{array}$ & & $\begin{array}{c}0.002 \\
(0.043)\end{array}$ & & & $\begin{array}{c}0.034 \\
(0.073)\end{array}$ & & $\begin{array}{c}0.046 \\
(0.068)\end{array}$ & \\
\hline Age 55-59 & & $\begin{array}{l}-0.112 \\
(0.046)\end{array}$ & ** & $\begin{array}{l}-0.096 \\
(0.045)\end{array}$ & ** & & $\begin{array}{l}-0.016 \\
(0.073)\end{array}$ & & $\begin{array}{c}0.019 \\
(0.068)\end{array}$ & \\
\hline Age $60-64$ & & $\begin{array}{l}-0.218 \\
(0.049)\end{array}$ & * & $\begin{array}{l}-0.164 \\
(0.052)\end{array}$ & * & & $\begin{array}{l}-0.023 \\
(0.073)\end{array}$ & & $\begin{array}{c}0.025 \\
(0.069)\end{array}$ & \\
\hline Age 65-69 & & $\begin{array}{l}-0.263 \\
(0.055)\end{array}$ & * & $\begin{array}{l}-0.194 \\
(0.057)\end{array}$ & * & & $\begin{array}{l}-0.078 \\
(0.073)\end{array}$ & & $\begin{array}{c}0.007 \\
(0.069)\end{array}$ & \\
\hline Age $70-74$ & & $\begin{array}{l}-0.345 \\
(0.053)\end{array}$ & * & $\begin{array}{l}-0.254 \\
(0.056)\end{array}$ & * & & $\begin{array}{l}-0.090 \\
(0.073)\end{array}$ & & $\begin{array}{c}0.009 \\
(0.069)\end{array}$ & \\
\hline Age 75+ & & $\begin{array}{l}-0.435 \\
(0.052)\end{array}$ & * & $\begin{array}{l}-0.330 \\
(0.056)\end{array}$ & * & & $\begin{array}{l}-0.166 \\
(0.072)\end{array}$ & * & $\begin{array}{l}-0.050 \\
(0.069)\end{array}$ & \\
\hline Net worth - 2nd Quartile & & $\begin{array}{l}-0.129 \\
(0.038)\end{array}$ & * & $\begin{array}{l}-0.105 \\
(0.035)\end{array}$ & * & & $\begin{array}{l}-0.278 \\
(0.094)\end{array}$ & * & $\begin{array}{l}-0.234 \\
(0.082)\end{array}$ & * \\
\hline Net worth - 3rd Quartile & & $\begin{array}{l}-0.168 \\
(0.046)\end{array}$ & * & $\begin{array}{l}-0.140 \\
(0.043)\end{array}$ & * & & $\begin{array}{l}-0.327 \\
(0.098)\end{array}$ & * & $\begin{array}{l}-0.293 \\
(0.087)\end{array}$ & * \\
\hline Net worth - 4th Quartile & & $\begin{array}{l}-0.146 \\
(0.057)\end{array}$ & * & $\begin{array}{l}-0.117 \\
(0.054)\end{array}$ & ** & & $\begin{array}{l}-0.342 \\
(0.105)\end{array}$ & * & $\begin{array}{l}-0.324 \\
(0.093)\end{array}$ & * \\
\hline Male & & $\begin{array}{c}0.033 \\
(0.015)\end{array}$ & $\star \star$ & $\begin{array}{c}0.022 \\
(0.015)\end{array}$ & & & $\begin{array}{c}0.022 \\
(0.016)\end{array}$ & & $\begin{array}{l}-0.003 \\
(0.016)\end{array}$ & \\
\hline High School & & $\begin{array}{c}0.051 \\
(0.019)\end{array}$ & * & $\begin{array}{c}0.040 \\
(0.019)\end{array}$ & ** & & $\begin{array}{c}0.190 \\
(0.016)\end{array}$ & * & $\begin{array}{c}0.116 \\
(0.016)\end{array}$ & * \\
\hline Vocational School & & $\begin{array}{c}0.183 \\
(0.022)\end{array}$ & * & $\begin{array}{l}0.150 \\
0.021\end{array}$ & * & & & & & \\
\hline Bachelor's Degree & & $\begin{array}{c}0.294 \\
(0.022)\end{array}$ & * & $\begin{array}{c}0.214 \\
(0.023)\end{array}$ & * & & $\begin{array}{c}0.292 \\
(0.026)\end{array}$ & * & $\begin{array}{c}0.148 \\
(0.026)\end{array}$ & * \\
\hline Presence of Children under 5 & & $\begin{array}{l}-0.039 \\
(0.021)\end{array}$ & *** & $\begin{array}{l}-0.005 \\
(0.020)\end{array}$ & & & $\begin{array}{l}-0.091 \\
(0.031)\end{array}$ & * & $\begin{array}{l}-0.047 \\
(0.030)\end{array}$ & * \\
\hline Presence of Children 5-18 & & $\begin{array}{c}0.028 \\
(0.019)\end{array}$ & & $\begin{array}{c}0.033 \\
(0.019)\end{array}$ & & & $\begin{array}{l}-0.095 \\
(0.014)\end{array}$ & * & $\begin{array}{l}-0.038 \\
(0.013)\end{array}$ & * \\
\hline Married & & $\begin{array}{c}0.081 \\
(0.020)\end{array}$ & * & $\begin{array}{c}0.016 \\
(0.020)\end{array}$ & & & $\begin{array}{c}0.041 \\
(0.019)\end{array}$ & ** & $\begin{array}{c}0.026 \\
(0.018)\end{array}$ & \\
\hline Parent & & $\begin{array}{l}-0.053 \\
(0.021)\end{array}$ & $\star *$ & $\begin{array}{l}-0.077 \\
(0.021)\end{array}$ & * & & $\begin{array}{c}0.032 \\
(0.019)\end{array}$ & & $\begin{array}{l}-0.013 \\
(0.018)\end{array}$ & \\
\hline Employed & & & & $\begin{array}{c}0.059 \\
(0.028)\end{array}$ & ** & & & & $\begin{array}{c}0.047 \\
(0.021)\end{array}$ & ** \\
\hline Income & & & & $\begin{array}{c}0.202 \\
(0.033)\end{array}$ & * & $\begin{array}{c}0.401 \\
(0.015)\end{array}$ & * & & $\begin{array}{c}0.337 \\
(0.016)\end{array}$ & * \\
\hline Risk & & & & $\begin{array}{c}0.065 \\
(0.025)\end{array}$ & * & & & & $\begin{array}{c}0.175 \\
(0.042)\end{array}$ & * \\
\hline Constant & $\begin{array}{l}5.113 \text { (0.299) }\end{array}$ & $\begin{array}{c}8.245 \\
(0.157)\end{array}$ & * & $\begin{array}{c}6.503 \\
(0.308)\end{array}$ & * & $\begin{array}{c}4.455 \\
(0.144)\end{array}$ & $\begin{array}{c}7.544 \\
(0.193)\end{array}$ & * & $\begin{array}{l}4.947 \\
(0.216)\end{array}$ & * \\
\hline Location variables & NO & YES & & YES & & NO & YES & & YES & \\
\hline $\begin{array}{l}\text { R-squared } \\
\text { Sample Size }\end{array}$ & $\begin{array}{l}0.221 \\
2669\end{array}$ & $\begin{array}{l}0.330 \\
2689\end{array}$ & & $\begin{array}{l}0.377 \\
2669\end{array}$ & & $\begin{array}{l}0.285 \\
4700\end{array}$ & $\begin{array}{l}0.218 \\
4727\end{array}$ & & $\begin{array}{l}0.315 \\
4700\end{array}$ & \\
\hline
\end{tabular}

Source: Authors' calculations based on the Luxembourg Wealth Study, Beta-version (October 2006).

Note: Significance levels are ${ }^{*}-1 \%,{ }^{* *}-5 \%,{ }^{* * *}-10 \% ;{ }^{1}$ Variables are in logs 
Table C.3. Within- and between-country differences in the wealth and income effect across age groups. Dependent variable: total expenditure ${ }^{1}$

Robust Standard Errors in Parentheses

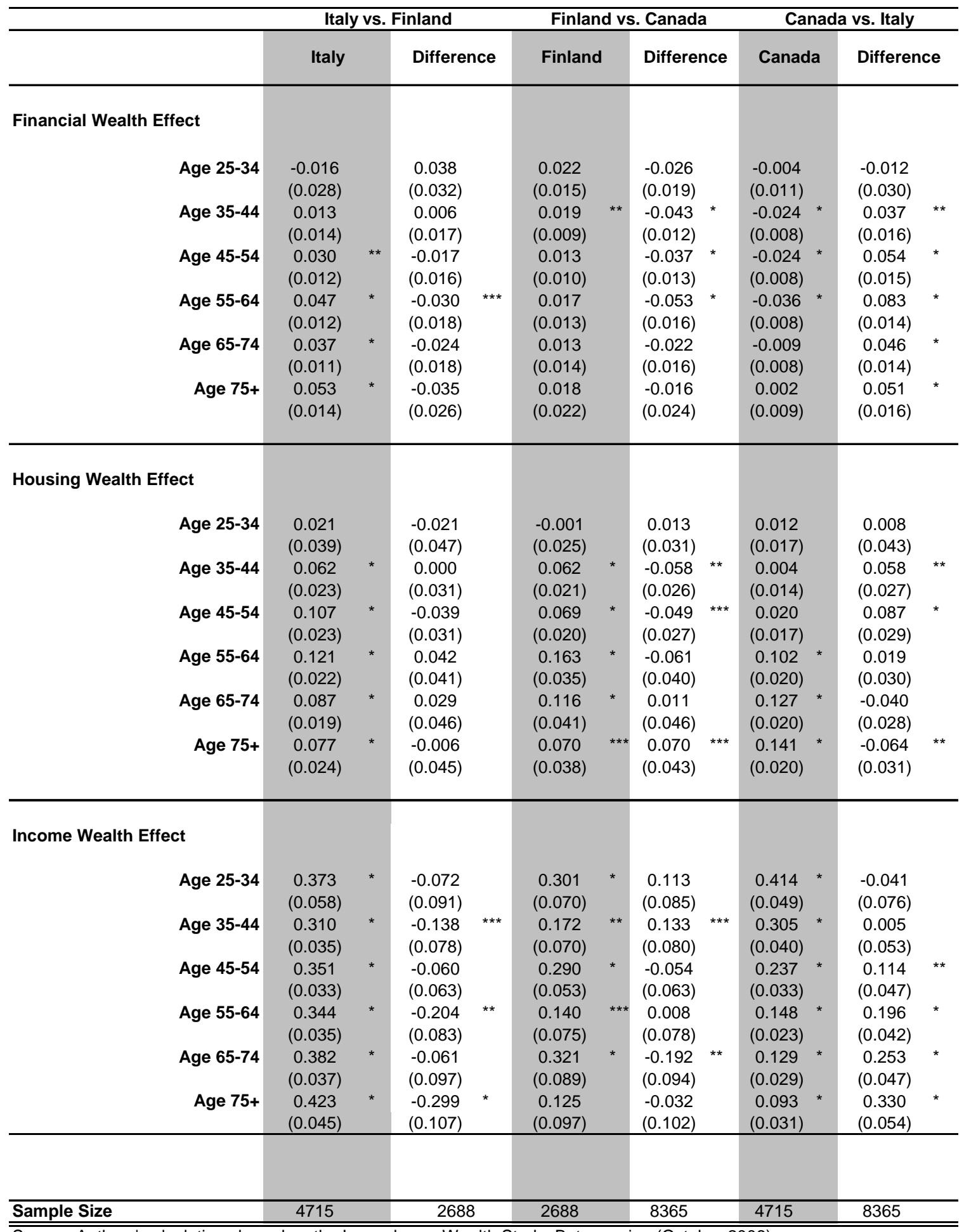

Source: Authors' calculations based on the Luxembourg Wealth Study, Beta-version (October 2006).

Note: Significance levels are ${ }^{*}-1 \%,{ }^{*}-5 \%,{ }^{* \star *}-10 \% ;{ }^{1}$ Variables are in logs 